\title{
Does James have a Place for Objectivity?
}

A Response to Misak

\section{Steven Levine}

\section{(2) OpenEdition Journals}

Electronic version

URL: http://journals.openedition.org/ejpap/551

DOI: 10.4000/ejpap.551

ISSN: 2036-4091

Publisher

Associazione Pragma

\section{Electronic reference}

Steven Levine, «Does James have a Place for Objectivity? », European Journal of Pragmatism and American Philosophy [Online], V-2 | 2013, Online since 24 December 2013, connection on 22 April 2019. URL : http://journals.openedition.org/ejpap/551 ; DOI : 10.4000/ejpap.551

This text was automatically generated on 22 April 2019.

\section{(c) $(1)$}

Author retains copyright and grants the European Journal of Pragmatism and American Philosophy right of first publication with the work simultaneously licensed under a Creative Commons AttributionNonCommercial-NoDerivatives 4.0 International License. 


\section{Does James have a Place for Objectivity?}

A Response to Misak

Steven Levine

1 In her new book The American Pragmatists Cheryl Misak provides a reading of the history of American Pragmatism in which it is composed of two related yet distinct types of pragmatism. She characterizes the debate between these two types of pragmatism as a debate between

those who assert (or whose view entails) that there is no truth and objectivity to be had anywhere and those who take pragmatism to promise an account of truth that preserves our cognitive aspiration of getting things right. On the one side of the debate we have Richard Rorty and his classical predecessors (James and Dewey) holding that there is no truth at which we might aim - only agreement within a community or what works for an individual or what is found to solve a problem. On the other side of the divide, we have those who think of pragmatism as rejecting an ahistorical, transcendental, or metaphysical theory of truth, but nonetheless being committed to doing justice to the objective dimension of human inquiry - to the fact that those engaged in deliberation and investigation take themselves to be aiming at getting things right, avoiding mistakes, and improving their beliefs and theories. On this more objective kind of pragmatism, which emanates from Wright and Peirce, the fact that our inquiries are historically situated does not entail that they lack objectivity. (Misak, 2013: 3)

2 Others have offered this "two pragmatism" reading, but no one has articulated it as well or with such historical thoroughness. In making vivid this contrast, and letting us see what is at stake in it, Misak's book performs an important service for those interested in the past and future of pragmatism.

3 Misak's account is not neutral. Instead she intervenes into the debate and argues that the Peirceian line of pragmatism, which she claims includes C. I. Lewis and Wilfrid Sellars, represents the best that pragmatism has to offer. But in her zeal to distinguish this line of pragmatism from the Jamesian line, the one that supposedly culminates in Rorty's dismissal of objectivity, Misak overstates her case. The notion that James and Dewey 
thought that there is, in Misak's words, "no truth and objectivity to be had anywhere" is in my view palpably false and accepts pragmatism's bad press rather than corrects it. In this response I try to provide this correction by showing that James - who for reasons of space is the only figure I can discuss - has a place for objectivity in his thought. The point of doing this is to cast doubt on the cogency of the "two pragmatism" reading of the pragmatic tradition.

Before I get to James, however, let me first signal some important areas of agreement. First, I agree with Misak that the "eclipse narrative" about pragmatism is a misleading interpretive device; that pragmatism was not simply killed off by analytical philosophy but was absorbed by it in complex ways. Her detailed telling of this alternative account of the history of pragmatism is fascinating and enlightening. Second, I agree with Misak that James and Dewey (and of course Rorty) do not do justice to the fact that truth is a distinct norm of thought and inquiry that cannot be reduced to either warrantedness or to what works (in the way of thought). Although I do not think that Misak does justice to the complexity of James' theory of truth one can agree that James was not careful enough in articulating his theory, sometimes leaving the reader with a sense that he thinks that truth is what works or is satisfying for me or for you. Misak's attempt to distance what is best in pragmatism from this incorrect view of truth is justified.

5 My disagreement with Misak does not so much concern truth, but objectivity. Truth and objectivity are of course related. In thinking about how one's thought and experience can be answerable to a world that is distinct from it we are thinking about how we can get that world right by having true beliefs. But the issue of objectivity is not quite the same as that of truth. Here is how Misak frames the issue of objectivity as it bears on the debate between the two pragmatisms:

One kind of pragmatism thinks that our history and evolution makes us into the interpretive engines we are and, although we cannot completely pry apart interpretation from the truth of the matter, there nonetheless is a matter that we are interpreting. That is Peirce, and we shall see, C. I. Lewis. The other kind of pragmatism thinks that not even by abstraction can we say that there is something that stands apart from our interpretation of it. That is Dewey and, in a different sort of way, James and Schiller. (Misak, 2013: 116)

6 Here Misak connects the objectivity issue to the threat of Idealism: can one's philosophical account of experience and thought avoid an Idealism that thinks that the nature and existence of the world is dependent on our interpretations of it? Can one make sense of the fact that our experience and thought is constrained by and answerable to a world that stands apart from our take on this world? For all pragmatists any answer to this question must avoid the Myth of the Given, the myth that, in Misak's words, we can completely pry apart our interpretations from the interpreted matter and get at the matter itself directly. Here, without conceptual mediation, the nature of reality, i.e., its intrinsic categorical structure, would be Given simply though our mirroring or representing it. ${ }^{1}$ Instead, the pragmatist thinks that our very ability to have experiences and thoughts about the world presupposes that certain acquired conditions, i.e., a sign system or conceptual scheme, habitual associations, etc. already be in place to inform our interpretations of the matter at hand. In light of this Misak's claim becomes this: Peirce and C. I. Lewis (and Sellars) can, without falling prey to the Myth of the Given, account for the fact that our experience and thought is answerable to something independent of it, while James, Dewey, (and of course Rorty), cannot. 
7 How can I resist this claim? Misak's specific brief against James focuses on two things: 1) his subjectivism about truth, i.e., his view that truth is what is expedient for me or for you as opposed to what is expedient for a community over time, and 2) James' attempt, in "The Will to Believe," to expand the pool of evidence that a subject can bring to bear for the truth of a belief. I have already admitted that James' "vulgar" account of truth, to the extent that it is his theory, is not acceptable; and others have already convincingly challenged Misak's reading of "The Will to Believe." Instead of focusing on these two issues I am going to discuss another aspect of James' thought that Misak completely ignores, his teleological account of the mind. I do so because it is here that one gets James' account of objectivity into view. By ignoring this aspect of his work, Misak gives a very one-sided account of James, one that reverberates through her whole history of pragmatism.

8 For example, it is only by ignoring the teleological account of mind that Misak can plausibly claim that Peirce was a larger influence on C. I. Lewis than James. While Lewis is correctly placed by Misak in the Peircian line of pragmatism insofar as he has a notion of objective constraint, one gets no sense from her account that the basic thought at the center of his Conceptualistic Pragmatism - namely, that a subject's "thick experience" of the world of objects in space and time is the result of an interpretation of the Given by a conceptual scheme that is pragmatically a priori, a scheme whose adoption is determined by the practical interest of the subject - is an application of James' teleological theory of mind. ${ }^{3}$ Similarly, Misak's account of Putnam is disfigured by the need to keep the two pragmatisms apart. Putnam takes it that his internal realism, the idea that common sense realism is consistent with conceptual relativity, has its origin in James' epistemic pluralism. ${ }^{4}$ But Putnam uses this "pragmatic realism" to argue against Rorty, who according to Misak culminates the Jamesian line of pragmatism. Clearly, the story about the two lines of pragmatism is not nearly so neat as Misak makes it.

So what is James' teleological account of the mind? In all periods of his work, James gives us a very basic account of the cognitive situation in which both human and non-human creatures find themselves. Creatures who are alive "inhabit environments which act on them and on which they in turn react" (James, 1981: 19). The environment acts on creatures by stimulating their sense organs. But according to James there is far more information in the environment than creatures can utilize to prepare their behavioral responses. Creatures are immersed in a chaotic stream of sensory data, what James calls a "much-at-onceness." To cope successfully with the environment creatures must organize the much-at-onceness through various forms of selection. At the most basic level, a creature's sense organs are selective mechanisms that, for physiological reasons, reliably respond to some sensory groupings and not others. The experiencing subject has no say here. Then, through attention, creatures further order the sensory flux that makes it past this initial sorting. Which features of the sensory flux a creature attends to and discriminates, and which features they ignore, is determined by the creature's interests. In creatures of higher complexity this ordering of the much-at-onceness is undertaken not just by acts of attention but by conceptions, "teleological instruments" that help us, in light of our interests, to practically handle the perceptual flux. " "Each act of conception results from our attention singling out some one part of the mass of matter-for-thought which the world presents, and holding fast to it, without confusion" (James, 1981: 437). Concepts are powerful instruments to further our basic practical and aesthetic interests because in holding fast to a pattern of attention over time they greatly expand our ability 
to foresee environmental tendencies and prepare for them, and to discern unity in complexity. Concepts, "by picking out from it [the much-at-onceness] the items which concern us, and connecting them with others far away, which we say 'belong' with them, we are able to make out definite threads of sequence and tendency; to foresee particular liabilities and get ready for them; and to enjoy simplicity and harmony instead of what was chaos" (James, 1979: 95).

Because of the ubiquity and importance of selection in mental life generally we can now see how mistaken it is to think of '“experience' as being equivalent to the mere presence of a certain outward order. Millions of items of the outward order are present to my senses which never properly enter into my experience. Why? Because they have no interest for me. My experience is what I agree to attend to. Only those items which I notice shape my mind - without selective interest, experience is an utter chaos" (James 1983: 119). ${ }^{6}$ In light of this we can see how James avoids the Given: while the flux of sensory data is given in the innocent sense that creatures have no control over whether they are exposed to it, this flux is not Given because what one experiences depends not on the intrinsic nature of the flux being impressed on our minds but on the way the flux is interpretively taken in light of one's interests, ideals, and ends. As James famously put it:

I, for my part, cannot escape the consideration, forced on me at very turn, that the knower is not simply a mirror floating with no foot-hold anywhere, and passively reflecting an order that he comes up and finds simply existing. The knower is an actor, and co-efficient of the truth on one side, while on the other he registers the truth which he helps to create. In other words, there belongs to mind, from its birth upward, a spontaneity, a vote. It is in the game, not a mere looker-on; and its judgments of the should-be, its ideals, cannot be peeled off from the body of the cogitandum as if they were excrescences, or meant, at most, survival (James, 1978: 21).

But does this not just show that Misak's diagnosis of James is right? It is one thing to say that knowers are a co-efficient of truth in the sense that truth cannot completely transcend human experience and practices of inquiry, another to say that the inquirer who registers the truth helps to create it. How can there be constraint by something that stands apart from our knowing and inquiring when the knower partially creates the truth - or better, the reality - that they come to know? So while James avoids the Given, he does so in so extravagant a fashion that he is lead into accepting an Idealism which cannot make sense of our answerability to something independent of thought, interpretation, and experience.

To avoid this outcome James must say that while knowers partially create the reality that they come to know, they are nonetheless constrained by this reality in coming to know it. But can this be said intelligibly?

Consider James' often used metaphor of a sculptor and a marble block. "The mind... works on the data it receives very much as a sculptor works on his block of stone" (James, 1981: 277). The sculptor does not create the marble block, nor can he do whatever he wants with it. The marble imposes limits on the sculptor. It is amenable to being cut up in some ways, but not others. Similarly, subjects do not create the sensory much-at-onceness, and it limits what subjects can think and do. "Sensations are forced upon us, coming we know not whence" (James, 1975: 117), and it provides "the mere matter to the thought of all of us indifferently" (James, 1981: 277). But while marble imposes limitations on the sculptor, there is no pre-determined way that the sculptor must cut the block of marble. There is a freedom of maneuver here. Similarly with "our sensations, That they are is undoubtedly 
beyond our control; but which we attend to, note and make emphatic in our conclusions depends on our own interests" (James, 1975: 118). ${ }^{7}$ So while sensations are "forced on us," "beyond our control," and provide the "matter to the thought of all of us indifferently," there is free play concerning how they are attended to, discriminated, and conceptualized.

There are two points to note here. When James says that "we attend to our sensations" he does not mean that we attend to our sensations as sensations - i.e., as "inner states." We don't attend to our sensations as sensations because, due to our habitual interests and modes of cognitive activity, what is given to a subject is a world of colored and shaped physical objects in space and time. In essence, naïve perception is intentional, and sensations are cognitive states that disclose basic features of the objective world, i.e., its voluminousness and qualitative character. ${ }^{8}$ Our being aware of sensations as inner states depends on our abstracting them out of our thick experience of spatio-temporal objects and, through an act of reflection, transposing them "into" the mind. An awareness of sensations as sensations therefore does not come first but last. As James puts it: "So far is it from being true that our first way of feeling things is the feeling of them as subjective or mental, that the exact opposite seems to be true. Our earliest, most instinctive, least developed kind of consciousness is the objective kind; and only as reflection becomes developed do we become aware of an inner world at all" (James, 1981: 679). If we stay true to lived experience, what is given to conscious subjects are not sensations but reality with all of its manifold properties.

Second, James does not think that there is a single way that the sensory flux must be taken up in our acts of attention and conceptualization, and so does not think that there is a single "reality." Reality is the product not only of a subject's ordering of the sensory flux by acts of attention and conceptualization, but also of past acts of attention and conceptualization, ones made by the subject and by their culture. These past acts become habituated, leading to typical ways of interpreting and apperceiving the sensory flux. These typical ways generate distinct "worlds." James mentions the world of common sense, the world of science, the ideal world of logic and mathematics, fictional and imaginary worlds, amongst others. None of these worlds are Given, even the common sense world of physical objects in space and time. For its basic conceptions

may have been successfully discovered by prehistoric geniuses whose names the night of antiquity has covered up; they may have been verified by the immediate facts of experience which they first fitted; and then from fact to fact and from man to man they may have spread, until all language rested on them and we are now incapable of thinking naturally in any other terms. (James 1975: 89) ${ }^{9}$

In other words, even the nature of the common sense world is not Given but partially "created" by knowers because this reality can only be discerned by subjects in light of their possession of habits of attention and use of conceptions (of thing, kind, subjects and attributes, causal influence, space and time, etc.) that were discovered in the past, found to "work," and passed on by language and culture.

17 James offers this admittedly speculative thesis because he was impressed by a philosophical lesson that he took from the advance of nineteenth century science. James noted that emerging micro-physical sciences use different basic conceptions and categories than "common sense," which itself uses different categories than those used by certain philosophical redescriptions of the real, for example Hume's skeptical account or Kant's critical account of reality. All of these schemes "work" in the sense that they 
successfully order the sensory flux in light of different ends. ${ }^{10}$ But if this is so, James thinks, we have little reason to think that the conceptions of common sense mirror or duplicate reality in itself any more than the conceptions of these other schemes. James draws a radical conclusion from this:

There is no ringing conclusion possible when we compare these types of thinking, with a view to telling which is the more absolutely true. Their naturalness, their intellectual economy, their fruitfulness for practice, all start up distinct tests of their veracity... Common sense is better for one sphere of life, science for another, philosophical criticism for a third; but whether either be truer absolutely, Heaven only knows. (James, 1975: 93)

But while we can draw no ringing conclusion concerning which scheme discloses the nature of the absolutely true or the real, we should not conclude from this that reality is "subjective." What the success of these different categorical schemes relative to our various purposes indicates is not subjectivism but conceptual pluralism: there are multiple realities or worlds because the sensory flux tolerates multiple ways of being taken up. We know this not on a priori grounds but on experiential grounds, namely, the fact that the different schemes are used and work. Based on the empirical evidence we ought not, as Rationalists do, suppose that there is a single way reality is, one that is gotten right by a single vocabulary. ${ }^{11}$ But not supposing this does not entail that there is no way that reality is, or that the sensory flux can be taken in any way. As James says:

[T] here is something in every experience that escapes our arbitrary control. If it be a sensible experience it coerces our attention; if a sequence, we cannot invert it; if we compare two terms we come to only one result. There is a push, an urgency, without our very experience, against which we are on the whole powerless, and which drives us in a direction that is the destiny of our belief. (James, 1975a: 45)

The sensory flux, once attended to and apperceived as a reality, dictates to our experience. Using an example from the world of sense, someone counting a constellation of seven stars, James says:

A fact virtually pre-exists when every condition of its realization save one is already there. In this case the condition lacking is the act of the counting and comparing mind. But the stars (once the mind considers them) themselves dictate the result. The counting in no wise modifies their previous nature, and, they being what and where they are, cannot fall differently... Undeniably something comes by the counting that was not there before. And yet, that something was always true. In one sense you create it, and in another sense you find it. (James, 1975a: 56) ${ }^{12}$

Here we can see how James' view makes a place for objectivity. While you "can't weed out the human contribution" (James, 1975: 122) in isolating "the real," for facts are only disclosed to creatures like us in light of the selective activity of the mind - an activity that itself "builds out" and is in that sense partially creative of reality - the facts which are disclosed through this activity are already there to be found and "agreed with." Any discussion of James' theory of truth must start here, with this account of objectivity already in place. While one might find that his theory of truth is not satisfactory, one will see it in its proper context, a context in which subjects, in light of their interests, discover or find out how the world already is.

There is a final question that needs consideration: how do we know that there is an indifferent sensory matter that the various realities or worlds fit? If one's answer is that we know this through a direct introspective awareness then one would endorse the Myth of the Given, the myth, in this case, that one can 'pry apart' one's interpretation of the sensory matter and get directly to the matter itself. 

first we can "speculatively image a state of 'pure' experience" (James, 1975a: 43) but we cannot experience it. We cannot experience the sensory flux "pure" because, as we saw above, the sensory matter has already been ordered by past acts of attention, discrimination, and conceptualization. The sensory flux is not "seen" but posited through a type of "abstraction" to make sense of 1) the experiential difference between our being sensuously acquainted with something and our merely thinking about it, and more importantly for us, 2) the fact that experience is resisted..$^{13}$ On this view, there is no position outside of experience that allows us, in advance as it were, to isolate the resisting sensuous matter given in our experience; rather we find, within experience, that certain of our activities are resisted while others are not. In essence we can only know which interpretive takings of the sensory matter work and which don't by trying, through experiments in our thought and action. On this account, it is the resistance that we experience in these experiments that licenses us to posit a resisting sensory matter in experience, not our direct acquaintance with the sensory matter.

The second account, in contrast, claims that we can be directly acquainted with the sensory flux. While the sensory flux is not graspable it can, in certain circumstances, be glimpsed.

Reality independent of human thinking... seems a very hard thing to find. It reduces to what is just entering into experience and yet to be named, or else to some imagined aboriginal presence in experience, before any belief about the presence has arisen, before any human conception has been applied. It is what is absolutely dumb and evanescent, the mere ideal limit of our minds. We may glimpse it, but we never grasp it; what we grasp is always some substitute for it which previous human thinking has peptonized and cooked for our consumption. (James, 1975: 119-20)

While in most cognitive situations the sensory flux is peptonized by previous human thinking, in certain marginal situations of consciousness, for example, when one is in a semi-coma from sleep, drugs, or illness, or perhaps when one has certain "mystical" experiences, one can glimpse the sensory flux itself. For James, especially in his late work, this is a glimpse into "the deeper features of reality" (James, 1979a: 54), the fact that reality is continuous rather than discrete, plural rather than one. The question is whether this is a glimpse of the Given?

One might think so because it seems that in having this glimpse we are seemingly getting to the sensory flux itself without any conceptual or interpretive mediation - and so completely prying apart our interpretations from the matters they are interpretations of. ${ }^{14}$ But to know whether something is a form of the Given one must know its function; does it play a foundational role in our system of knowledge, or does it immediately impress upon one's mind the categorical nature of reality itself? The sensory flux by itself does not play any epistemic role for James, it bears no cognitive inferences, and provides no warrant, so it is not a version of the epistemic Given. But does this glimpse give us access to the categorical nature of reality, to the really real? In one way yes, in another no. As we mentioned above, in his late work James repeatedly says that pre-conceptual experience is more revealing of the true nature of reality than conceptual experience. But is the categorical structure of what is revealed in marginal states of consciousness "imposed on the mind as a seal imposes an image on melted wax" (in Sellars' phrase)? And does this imposed categorical structure then inform our grasp of the world? What is important to realize is that for James the sensory flux is a much-at-onceness that contains a plenitude 
or overabundance of qualities and relations. James' pluralism applies to both the sensory realm and to the conceptual realm. For James the way things categorically are cannot be Given to a subject by their glimpse of the sensory flux because there is no single way things are in the flux. Our glimpse of the sensory flux is a glimpse of the plurality of things, not of reality's single intrinsic nature, and so there is no single categorical structure to be passed along to inform our grasp of the world. In this way, even at his most mystical, James avoids what is pernicious in the Myth of the Given. ${ }^{15}$

\section{BIBLIOGRAPHY}

FLOWERS E \& MURPHY M., (1977), A History of Philosophy in America, New York, G. P. Putnam's Sons.

JAMEs W., (1975), Pragmatism, Cambridge, Harvard University Press.

JAMEs W., (1975a), The Meaning of Truth, Cambridge, Harvard University Press.

JAMES W., (1978), Essays in Philosophy, Cambridge, Harvard University Press.

JAMEs W., (1979), The Will to Believe, Cambridge, Harvard University Press.

JAMEs W., (1979b), Some Problems of Philosophy, Cambridge, Harvard University Press.

JAMES W., (1981), Principles of Psychology, Cambridge, Harvard University Press.

JAmes W., (1983), Essays in Psychology, Cambridge, Harvard University Press.

KLEIN A., (forthcoming), "Science, Religion and 'The Will to Believe'."

LEWIS C. I., (1968), “Autobiography," in Schlipp P. A. ed., The Philosophy of C. I. Lewis, Lasalle, IL, The Open Court Publishing Company.

MISAK C., (2013), The American Pragmatists, Oxford, Oxford University Press.

O'SHEA J., (2000), "Sources of Pluralism in William James," in Baghramian M. ed., Pluralism: The Philosophy and Politics of Diversity, London, Routledge Press.

PANCHERI L., (1971), “James, Lewis, and the Pragmatic A priori,” Transactions of the Charles S. Peirce Society 7,3 .

PUTNAM H., (1987), The Many Faces of Realism, Chicago, Open Court.

SELLARS W., (1981), "Foundations for a Metaphysics of Pure Process," The Monist 64.

\section{NOTES}

1. There are many versions of the Myth of the Given, the most famous being epistemic. This is the myth that there can be non-conceptual episodes of immediate awareness that have epistemic authority simply through being Given. The myth we are interested in here is more basic, involving the categorical nature of what is Given rather than its epistemic status. In Sellars' words, this is the myth that "the categorical structure of the world - if it has a categorical 
structure - imposes itself on the mind as a seal imposes an image on melted wax" (Sellars, 1981: 11, emphasis in original omitted).

2. See Klein forthcoming.

3. Unfortunately, I cannot justify this claim here, although one will be able to see, after reading my account of James' theory of mind, how closely Lewis adheres to it. It is true that Lewis learned a lot from Peirce, often via Royce. But as Lewis himself said, the "experience" of reading Peirce "served to revive earlier trains of thought, particularly such as found their initiation under James' tutelage" (Lewis, 1968: 17). And it is true, as Misak points out, that Lewis was critical of James, especially on the issue of truth (see Lewis, $1968: 11$ ). But this does not rule out the fact that Lewis' basic account of how mind imposes order on the chaos of the Given is Jamesian in nature. See Pancheri (1971) and the chapter on Lewis in Flowers \& Murphy (1977).

4. See Lecture 1 of Putnam (1987).

5. James actually identifies many more levels of selection, some pre-personal and some personal, but these three are sufficient for our purposes.

6. In saying that "experience is what I agree to attend to" James overstates his case. James' overall view is much less voluntarist than it seems from this passage insofar as, as we mentioned above, he posits multiple levels of selection, most of which do not involve conscious "agreement" or "free choice."

7. One would need to make things more complex here by accounting for the fact that some sensations seem, due to the way their intrinsic properties interact with our sense organs, more forced on us than others.

8. The relation of sensation and perception is a tricky issue in James. On the one hand, James insists that sensations are not atomic items that can be compounded into more complex perceptual states, but are themselves cognitive states in which simple features of the objective world come into view. On the other hand, he accepts that perception involves a form of "apperception" - an interpretation of sensation by "ideas already in the mind" (James, 1981: 751) - and that "Perception always involves Sensation as a portion of itself" (James, 1981: 651). What we need, I think, to make sense of his view here is a distinction between a "phenomenology of perception" and a "transcendental analysis of perception." From the phenomenological point of view, sensations are not states that compound into more complex states, but are singular cognitive states. So when we go from having a conscious experience of volume and quality, for example when we are just waking up, to a more complex conscious experience, perceiving the room that we are waking up in, we don't go from atomic sensory impressions to perceptual experiences of the room made up of those atomic impressions; rather, we go from having a single conscious state that has a simple content or object to having a completely new conscious state with a much more complex content or object. But from the point of view of transcendental analysis, we perceive a room as having sensory qualities because there is, within the perceptual act, an apperception of sensations. The key point is that sensations, even from this point of view, should not be understood as sensory atoms but as states that disclose features of the objective world. What apperception adds to sensation is not openness to the world, but relation to a selfidentical object. The notion that a portion of the stream of experience can be about the same thing at different times is not internal to sensations themselves, but is introduced into the sensory stream through apperception and conceptualization (see: 434).

9. One wonders whether Sellars' famous genius Jones was inspired by James' pre-historic geniuses.

10. The conceptions that comprise these schemes are pragmatically a priori. Although they are instituted because they help make sense of the sensory flux, once instituted "[n]o experience can upset them. On the contrary, they apperceive every experience and assign it to its place" (James, 1975a: 42). Although these schemes can be revised or abandoned when they no longer "work," once instituted they are constitutive of the meaning of the items in the domain that they make 
possible. One can see how those interested in what Michael Friedman calls the 'relative a priori' stand, whether they know it or not, in James' shadow.

11. Here we find a deep disagreement between James and Peirce. While James often endorses the Peirceian idea that an idea is true if it holds up in the hypothetical long run, he does not, at least as I read him, accept the idea that in the long run we will necessarily converge on a single vocabulary that carves reality at its single true joints. He thinks that it is an open question whether we will converge on such a vocabulary, or whether, even at the ideal limit of inquiry, conceptual pluralism will be order of the day. However - and this is my point - in either case James thinks that we can still have a robust account of objectivity, an account of how the mind is answerable to the world. The question of whether there is constraint is distinct from whether there is necessary convergence.

12. This form of argument applies to all the other enumerated "realities" or "worlds." While a particle accelerator "creates" more reality in the sense that its use "builds out" reality, the facts found or discovered by these activities pre-exist the use of the accelerator.

13. Although on this account we don't experience the sensory flux directly, our account of it is still definable "in terms drawn from experience" (James, 1975a: 6) insofar as we experience resistance and the sensory nature of what is experienced. Hence, it stays within the bounds of James' Radical Empiricism.

14. In his excellent paper "Sources of Pluralism in William James" Jim O'Shea argues that James' view here is not only a version of the Myth of the Given but a "veritable celebration of the myth" (2000: 39).

15. Thanks to Alex Klein for incisive comments on this paper.

\section{AUTHOR}

\section{STEVEN LEVINE}

University of Massachusetts, Boston

steven.levine[at]umb.edu 